\title{
Factors Affecting Participation In Wastewater Management Programs: Thalenoi Non-Hunting Area Phatthalung Province, Thailand
}

Surachet Chiramanee, Prince of Songkla University, Thailand Chidchanok Churngchow, Prince of Songkla University, Thailand Rotchanatch Darnsawasdi, Prince of Songkla University, Thailand

\begin{abstract}
The primary objective of this study was to investigate factors influencing the participation of families living within the ThaleNoi Non-hunting Area in processes or programs that reduce the discharge of untreated wastewater generated in Spikerush dyeing in Thailand. We distributed questionnaires to the 850 families in the study region whose livelihoods included Spikerush dyeing. The quantitative data for socioeconomic condition and political issue of the study area were collected. Using linear regression, we found that 5 of the 15 variables tested were significantly related to a family's likelihood of participating in processes or programs that reduce the discharge of untreated wastewater $(Y)$ according to the equation: $Y=0.169 X_{9}+0.272 X_{12}+$ $0.131 X_{13}+0.878 X_{14}+0.317 X_{15}-0.197$. The five significant variables include (1) pressure from relatives or other individuals to join wastewater management programs $\left(X_{9}\right)$, (2) recognition of the importance of preserving public properties $\left(X_{12}\right)$, (3) participation in community meetings $\left(X_{13}\right)$, (4) ability to acknowledge problems associated with the discharge of untreated wastewater $\left(X_{14}\right)$, and (5) participation in political issues $\left(X_{15}\right)$. Given these results, we recommend the use of a Participatory Learning Process to educate local people regarding the danger that heavy metal contamination related to Spikerush dyeing wastewater can pose to the health of people and biodiversity in the area. We also advocate Participatory Action Research (PAR) so that stakeholders can discuss and select the most agreeable solutions for the disposal and treatment of wastewater from Spikerush dyeing.
\end{abstract}

Keywords: Wastewater Management Programs; Spikerush Dyeing in Thailand; Heavy Metal Contamination

\section{INTRODUCTION}

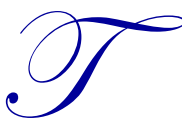

haleNoi Non-hunting Area, located north of Songkhla Lake, is a large freshwater swamp covering 114,250 acres in the provinces of Nakhon Si Thammarat, Songkhla, and Phatthalung in southern Thailand Figure 1.

ThaleNoi is critical to surrounding areas and the local community, including over 2,000 families, for a number of reasons. It serves as a freshwater reservoir, a buffer that protects against flooding and erosion, and a filter for toxic chemicals. It supports local agriculture, fisheries, transportation, tourism, and cultural activities (Office of Bio-Diversity, 1999). In addition, ThaleNoi provides resources for two of the primary income sources of local inhabitants: (1) preserved fish products (e.g., dried and salted fish) and (2) Spikerush basketry products (e.g., floor mats, handbags, hats, plate and glass mats). 


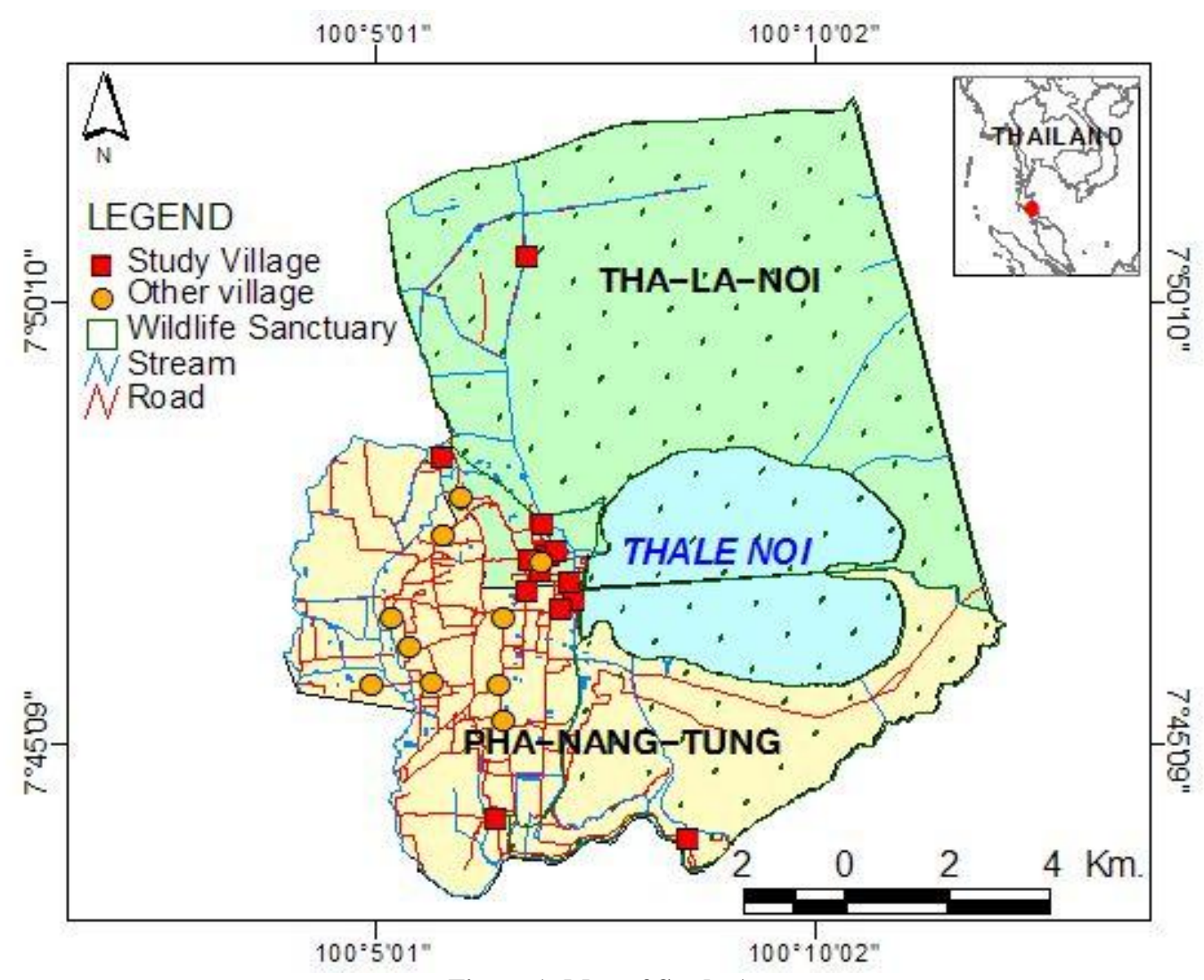

Figure 1: Map of Study Area

Source: Geographic Information System (GIS) Center of Prince of Songkla University Hatyai, Songkhla Thailand

Finally, wetlands in ThaleNoi support native biodiversity, including several species of freshwater plants and animals as well as local and migratory birds that serve as tourist attractions. Because of the vast number of avian species, the Khuan Khisien region of ThaleNoi was registered as the first Ramsar Site in Thailand in 1998 (Ungkaprechaset,1985). There were 149 types of birds in 40 species. Among these, 116 were local birds and 33 were migratory, most of which were living in Khuan Khisien area so this area was registered as the first Ramsar Site of Thailand in the year 1998. ThaleNoi's importance to native biodiversity and the survival and livelihood of local people, recent declines in water quality are of major concern. Researchers have reported levels of heavy metals; including copper, zinc, nickel, cadmium, and chromium, that drastically exceed allowable limits (Chiengmai), 1979, Maneepong \& Rak-keaw, 1998 and Department of Pollution Control, 2009). Heavy metal contamination can lead to a variety of health problems in humans, including fatigue, pale skin, anemia, and paralysis (from overexposure to lead); skin and lung cancer, stomach disorders, and colon diseases (chromium); Monday fever (zinc); osteoporosis and aching bones and joints (cadmium); and nausea, vomiting, and deterioration of taste sensitivity (copper) (Mahasarakam University, 2011) In addition, heavy metal contamination has reduced fecundity and survival of local and migratory birds in other wetland regions throughout the world.

Much of the heavy metal contamination in this region has been attributed to the release of untreated wastewater from Spikerush dyeing processes. It is estimated that, for the last 30 years, Spikerush dyeing has been the main income source for over 1,000 local households.

Attempts have been made by the Thai government and several organizations to reduce water contamination. For example, the Conservation Area and Natural Wildlife Act (1992 A.D) contain an article that explicitly prohibits the discharge of toxic substances into natural waterways. However, local people continue to discharge wastewater from Spikerush dyeing despite this legislation was observed from the field and from the depth interview with head of the village

(Chiramanee, personal observation). In addition, four Spikerush dyeing 
wastewater treatment plants were built by the Department of Pollution Control in 2008, and six small plants were built by Thaksin University (Phatthalung Campus) in 2010. However, these plants were later abandoned. Given the failure of these attempts at controlling wastewater disposal, our objectives in this study were to investigate factors influencing the participation of local people in processes or programs that reduce the discharge of untreated wastewater from Spikerush dyeing into natural waterways.

\section{METHODOLOGY}

We limited our analysis to the 850 families in the ThaleNoi Non-hunting Area whose primary income came from Spikerush dyeing. We distributed questionnaires to these families to determine socioeconomic data and political issues for the reduction of waste water in ThaleNoi. The Multiple Regressions Equation was used to analyze the obtained data. The number of samples required for the study must include at least 20 times the 15 research variables, resulting in a number of $\geq 300$ families (Hair, 1998). The number of 315 samples was then simple randomly selected from Spikerush dyers in Phanangtung and ThaleNoi Sub-districts in ThaleNoi Non-hunting Area.

\section{RESULTS}

We found that five variables were significantly correlated $\left(\mathrm{R}^{2}=.311\right)$ with a given family's participation in efforts to reduce the discharge of untreated wastewater from Spikerush dyeing: (1) pressure from relatives or other individuals to join wastewater management programs $\left(\mathrm{X}_{9}\right),(2)$ recognition of the importance of preserving public properties $\left(X_{12}\right)$ (Cohen and Uphoff, 1980), (3) participation in community meetings $\left(X_{13}\right)$, (4) ability to acknowledge problems associated with the discharge of untreated wastewater $\left(\mathrm{X}_{14}\right)$, and (5) participation in political issues $\left(\mathrm{X}_{15}\right)$ [Lundwist(1986)]. These five variables were related to a family's likelihood of participating in programs that reduce the discharge of untreated wastewater $(\mathrm{Y})$ according to the following relationship:

$\mathrm{Y}=0.169 \mathrm{X}_{9}+0.272 \mathrm{X}_{12}+0.131 \mathrm{X}_{13}+0.878 \mathrm{X}_{14}+0.317 \mathrm{X}_{15}-0.197$

\section{CONCLUSIONS AND RECOMMENDATIONS}

Given the results of our study, we recommend that Participatory Learning Process (PLP) should be conducted so that Spikerush product dyers and public people could learn and share knowledge and understanding in values, importance of ThaleNoi and problems the community is confronting including the contamination of the five heavy metals in ThaleNoi Non-hunting Area. Participatory Action Research (PAR) should be applied. In doing this all involved parties can discuss and select the most agreeable solutions in disposal and treatment of wastewater from the Spikerush product dyeing.

In addition, we suggest that studies be conducted to evaluate the effects of heavy metal contamination in birds and fish within the ThaleNoi Non-hunting Area. Finally, Spikerush dyers should be provided with regular medical check-ups given the potential health impacts of heavy metal contamination.

\section{AUTHOR INFORMATION}

Surachet Chiramanee is a Ph.D. candidate in Environmental Management, Prince of Songkla University, Hatyai, Songkhla, Thailand. He is Assoc. Prof in the field of public administration. Tel: +66 869580223 E-mail: Surachet2011@yahoo.com (Corresponding author)

Chidchanok Churngchow is a lecturer at the Faculty of Education Administration, Prince of Songkla University, Pattani Campus, Pattani, Thailand. He is a specialist in social science research methodology. Tel: +66 899751766. E-mail: cchicha@bung.pn.psu.ac.th

Rotchanatch Darnsawasdi is the Dean of Faculty of Environmental Management, Prince of Songkla University, Hatyai, Thailand. He is a specialist in environmental management and urban planning. Tel: +66 814783197 E-mail: rotchanatch.d@psu.ac.th 


\section{REFERENCES}

1. Chiengmai, N. N. (2009). Research Report on the Songkhla Lake Project 1978-1979. Prince of Songkla University and the National Environment Committee, Hatyai, Songkhla: Prince of Songkla University.

2. Cohen, J. M. and N. T. Uphoff. (1980). Participation's place in rural development: seeking clarity through specificity. World Development, 8.

3. Department of Pollution Control. (2009). The complete report for the treatment of wastewater from community industrial product of Skiperush dyeing in ThaleNoi area. Bangkok: Ministry of Natural Resources and Environment.

4. $\quad$ Fukuyama, S. (1995). Trust: the social virtues and the creation of prosperity. New York: Free press.

5. Hair, J. F., Aderson, R. E., Tatham, R. L., and Black, W. C. (1998). Multivariate Data Analysis (5 ${ }^{\text {th }}$ Edition). Upper Saddle River. NJ: Prentice Hall.

6. Lundwist, Lennart J. 1986. Do Politic Stauctures Matter in Environmental Politics? The American Behavioral Scientist, 17(5), 1-20

7. Mahasarakham University. (2010). Sicknesses caused by heavy metal contamination. Photocopied Documents. (No place and date of publication)

8. Maneepong, S and S. Rak-keaw. (1998). A study of chemical properties in residue in ThaleNoi and Thale Luang. Faculty of Natural Resources Management, Prince of Songkla University, Hatyai,Songkhla.

9. _ (1999). List of the national and international Ramsar sites in Thailand, Bangkok: Ministry of Science, Technology and Environment.

10. Ungkaprechaset, P. (1985). Changes in bird populations in ThaleNoi Non-hunting Area, Songkhla Province. Faculty of Natural Resources Management, Prince of Songkla University, Hatyai, Songkhla.

11. Walaisatein, P. (2005). Work procedure and techniques for development personnel. Bangkok: The Thailand Research Fund. 